\title{
Ureteric Reflux and Kidney Scarring in Children
}

\author{
JOHN E. S. SCOTT and J. M. STANSFELD \\ From the Departments of Surgery and Child Health, University of Newcastle upon Tyne, and \\ United Newcastle upon Tyne Hospitals
}

Vesico-ureteric reflux is commonly found in children who are investigated because of urinary tract infection. By allowing back-flow of infected urine from bladder into ureter, reflux may cause progressive damage to the upper urinary tract, such as dilatation of the ureter and scarring in the kidney. Hodson and Edwards (1960) noted that reflux was often associated with kidney scarring, and McGovern, Marshall, and Paquin (1960) made the striking statement that 'all upper urinary tracts with reflux are dying but at different rates'. Yet not everyone is convinced that the operative treatment of reflux is necessary. The occasional spontaneous disappearance of reflux when infection is controlled, and the markedly decreased incidence in adolescents and adults led Baker et al. (1966) to 'question whether the majority of children with reflux are not surgically overtreated'.

\section{Material and Methods}

We have studied our cases of urinary tract infection in children with a view to deducing the incidence of reflux and kidney scarring, and the relation between these two features. Cases in which the urinary infection was associated with an obstructive lesion or a neurogenic bladder were excluded from this series, which included 201 children.

The criteria for the diagnosis or urinary infection and the method of cystographic examination used to determine the presence of reflux were the same as described in a previous paper (Scott and Stansfeld, 1968). Scarring was deemed to be present in a kidney when the intravenous pyelogram showed diminution in parenchymal thickness in one or more areas, with clubbing of the associated calyx or calyces.

\section{Results}

Table I shows the incidence of reflux and scarring which were $55 \%$ and $42 \%$, respectively. Table II shows the relation between reflux and scarring in ureters and kidneys. Scarring was present in $61 \%$ of the kidneys associated with refluxing ureters, but in only $7 \%$ of the kidneys whose ureters did

\footnotetext{
Received March 1, 1968.
}

not reflux. Thus, scarring was over 8 times more frequent when there was reflux than when there was none. Again, there was reflux in $85 \%$ of the ureters whose kidneys were scarred, and in $22 \%$ of the ureters whose kidneys were normal; a fourfold difference. In short, while reflux is frequently but not invariably associated with kidney scarring, scarring seldom occurs without reflux.

The cases were also analysed in relation to the age at onset of symptoms and the duration of symptoms. Table III and Fig. 1 show the relation between reflux and scarring, and the age at onset of symptoms, and Table IV and Fig. 2 show the relation between reflux and scarring, and the duration of symptoms. Both reflux and scarring were found more frequently when symptoms started at an early age, or if they had been present for a long time.

\section{Discussion}

This analysis confirms the statements of Hodson and Edwards (1960), Hodson and Wilson (1965),

TABLE I

Incidence of Reflux and Scarring Among 201 Children with Urinary Tract Infection

\begin{tabular}{ll|c|c|c}
\hline & & Unilateral & Bilateral & Total \\
\hline Reflux .. & $\ldots$ & 63 & 48 & 111 \\
Scarring.. & $\ldots$ & 54 & 30 & 84 \\
\hline
\end{tabular}

\section{TABLE II}

Presence or Absence of Reflux and Scarring Among 201 Children with Urinary Tract Infection

\begin{tabular}{|c|c|c|c|c|}
\hline & & \multicolumn{2}{|c|}{ Reflux (ureters) } & \multirow{2}{*}{ Tota } \\
\hline & & Present & Absent & \\
\hline \multirow[t]{2}{*}{$\begin{array}{l}\text { Scarring } \\
\text { (kidneys) }\end{array}$} & $\begin{array}{l}\text { Present } \\
\text { Absent }\end{array}$ & $\begin{array}{l}97 \\
62\end{array}$ & $\begin{array}{r}17 \\
226\end{array}$ & $\begin{array}{l}114 \\
288\end{array}$ \\
\hline & Total & 159 & 243 & 402 \\
\hline
\end{tabular}




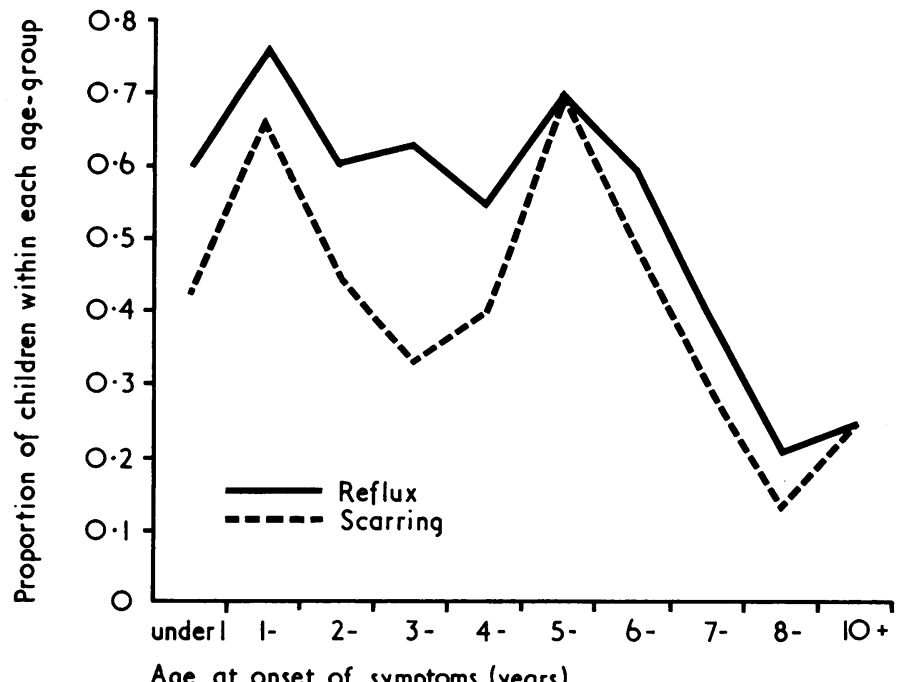

FIG. 1.-Incidence of reflux and scarring related to onset of symptoms.

and Smellie et al. (1964) that reflux is frequently associated with kidney scarring. However, the incidence of both these features is higher in our series, possibly because about two-thirds of our cases were collected from a paediatric urology clinic that has a surgical bias. Nevertheless, this cannot be the only explanation, since all children with 'surgical conditions' of the urinary tract other than ureteric reflux were excluded from the series.

Our finding that reflux occurred more often in children whose infection started at an early age was not unexpected, for though we do not know any observations relating reflux to age at onset of symptoms, there are reports relating it to age at time of investigation. Thus, Fisher (1965) found $76 \%$ of his cases of reflux in children under 6 years

TABLE III

Reflux and Scarring Related to Age at Onset of Symptoms

\begin{tabular}{|c|c|c|c|c|c|c|}
\hline \multirow{2}{*}{$\begin{array}{c}\text { Age at } \\
\text { Onset } \\
\text { (yr.) }\end{array}$} & & \multirow{2}{*}{$\begin{array}{l}\text { No. of } \\
\text { Cases }\end{array}$} & \multicolumn{2}{|c|}{ Reflux } & \multicolumn{2}{|c|}{ Scarring } \\
\hline & & & No. & $\begin{array}{l}\text { Propor- } \\
\text { tion }\end{array}$ & No. & $\begin{array}{l}\text { Propor- } \\
\text { tion }\end{array}$ \\
\hline $\begin{array}{ll}<1 & \ldots \\
1- & \ldots \\
2- & \ldots \\
3- & \ldots \\
4- & \ldots \\
5- & \ldots \\
6- & \ldots \\
7- & \ldots \\
8- & \ldots \\
10+ & \text { over } \\
\text { Unknown }\end{array}$ & $\begin{array}{l}\ldots \\
\ldots \\
. \\
\cdots \\
\ldots \\
\ldots \\
\cdots \\
\cdots \\
\cdots \\
\cdots \\
.\end{array}$ & $\begin{array}{r}27 \\
9 \\
29 \\
30 \\
29 \\
13 \\
16 \\
13 \\
14 \\
8 \\
13\end{array}$ & $\begin{array}{r}16 \\
7 \\
17 \\
19 \\
16 \\
9 \\
10 \\
5 \\
3 \\
2 \\
7\end{array}$ & $\begin{array}{l}0 \cdot 6 \\
0 \cdot 77 \\
0 \cdot 6 \\
0.63 \\
0.55 \\
0 \cdot 7 \\
0 \cdot 6 \\
0 \cdot 4 \\
0 \cdot 21 \\
0 \cdot 25 \\
0.54\end{array}$ & $\begin{array}{r}12 \\
6 \\
13 \\
10 \\
11 \\
9 \\
8 \\
4 \\
2 \\
2 \\
7\end{array}$ & $\begin{array}{l}0 \cdot 44 \\
0 \cdot 66 \\
0 \cdot 45 \\
0 \cdot 33 \\
0 \cdot 4 \\
0 \cdot 7 \\
0 \cdot 5 \\
0 \cdot 3 \\
0 \cdot 14 \\
0 \cdot 25 \\
0 \cdot 54\end{array}$ \\
\hline
\end{tabular}

of age, while Baker et al. (1966) commented upon the high incidence in young children, especially in the first two years. There is also support for the observation that scarring of the kidney is more common in those starting symptoms early in life, for Hodson and Wilson (1965) found that among 200 children with urinary tract infections, the 26 with scarred kidneys were all under 6 years old.

It seems evident that the combination of vesicoureteric reflux and infection leads to kidney scarring. What is not known is which comes first, the infection or the reflux; whether in fact the reflux is the result of infection, or whether it is of congenital origin and infection almost invariably follows. Either alternative can explain the high incidence of reflux in younger children. If infection is the primary lesion, it would most easily damage the vesicoureteric junction in the smaller child who has a thin bladder wall and short intramural ureter. On the other hand, it is likely that infants born with reflux

TABLE IV

Reflux and Scarring Related to Duration of Symptoms

\begin{tabular}{|c|c|c|c|c|c|}
\hline \multirow{2}{*}{$\begin{array}{c}\text { Duration of } \\
\text { Symptoms } \\
\text { (yr.) }\end{array}$} & \multirow{2}{*}{$\begin{array}{c}\text { No. of } \\
\text { Cases }\end{array}$} & \multicolumn{2}{|c|}{ Reflux } & \multicolumn{2}{|c|}{ Scarring } \\
\hline & & No. & $\begin{array}{l}\text { Propor- } \\
\text { tion }\end{array}$ & No. & $\begin{array}{l}\text { Propor- } \\
\text { tion }\end{array}$ \\
\hline $\begin{array}{l}<6 / 12 \\
6 / 12- \\
1-\quad \ldots \\
2-\quad \ldots \\
3-\quad \ldots \\
4-\quad \ldots \\
5+\text { over }\end{array}$ & $\begin{array}{l}44 \\
21 \\
39 \\
32 \\
12 \\
14 \\
26\end{array}$ & $\begin{array}{r}19 \\
11 \\
22 \\
19 \\
7 \\
10 \\
16\end{array}$ & $\begin{array}{l}0.43 \\
0.52 \\
0.56 \\
0.60 \\
0.58 \\
0.71 \\
0.60\end{array}$ & $\begin{array}{r}12 \\
7 \\
14 \\
16 \\
5 \\
7 \\
16\end{array}$ & $\begin{array}{l}0.27 \\
0.33 \\
0.36 \\
0.5 \\
0.42 \\
0.5 \\
0.6\end{array}$ \\
\hline
\end{tabular}




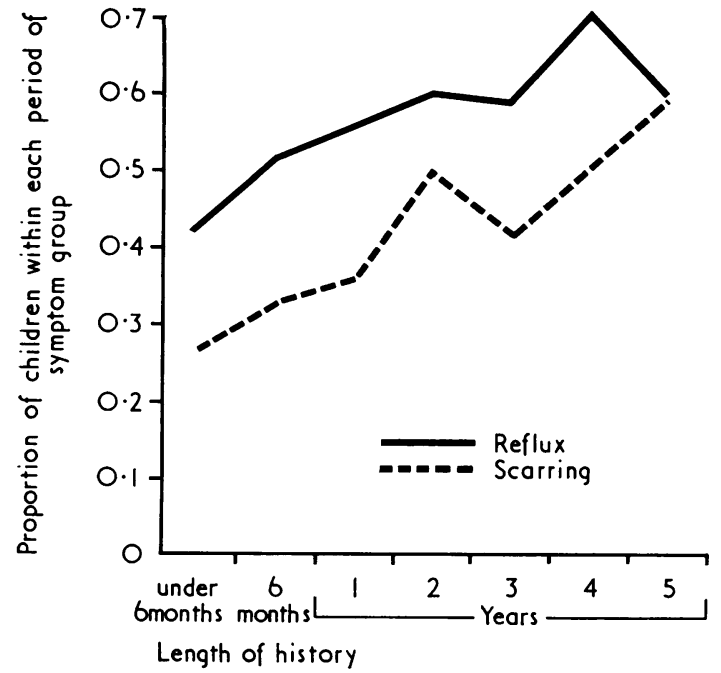

FIG. 2.-Incidence of reflux and scarring related to duration of symptoms.

would be particularly susceptible to infection in early life.

Smellie et al. (1964) found, as we have, that kidney scarring becomes more common as the duration of symptoms becomes longer. It seems reasonable to suppose that the longer infection and reflux are present, the more damage will be done to the kidney. The similar increasing incidence of reflux with longer histories is a new finding that needs to be explained, though once again it can be accounted for both by the infection causing reflux and the reflux causing infection hypotheses. Thus, it can be argued that the longer infection is present, the more chance there will be that the ureterovesical junction will be damaged. It can also be said that since infection will be more difficult to control when there is reflux present, there will consequently be more children having reflux amongst the chronic cases. A third explanation also occurs to us. It may be that our selection of cases has been biased, for we would be more likely to see children having long histories if their infections started early in life than if they became infected later, since, in the latter case, by the time they reached hospital many would be too old for referral to a paediatric clinic. It has already been noted that older children starting infections are less likely to have reflux, and the exclusion of some from the longer history cases would leave a relative preponderance of the more susceptible younger group. Even so, we think it unlikely that this is the whole explanation or that it invalidates our findings, since, when only children who began their infections before

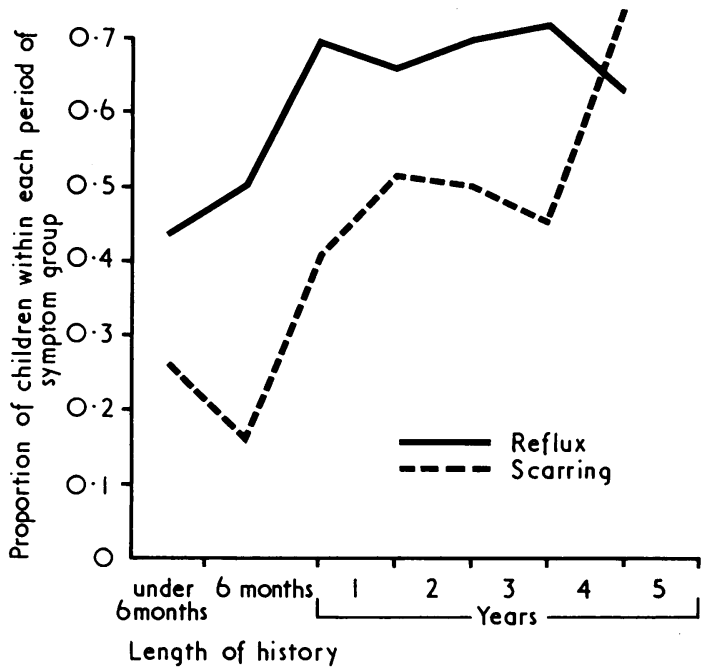

FIG. 3.-Incidence of reflux and scarring related to duration of symptoms in children infected under the age of 5 years.

5 years of age are considered, there is still the same rising incidence of reflux and scarring, with duration of symptoms (Fig. 3).

\section{Summary}

A series of 201 children with urinary infection is described. Children whose infection was associated with 'surgical conditions' of the urinary tract other than ureteric reflux were excluded.

It was found that $55 \%$ of the children had ureteric reflux and $42 \%$ had kidney scarring. Kidney scarring seldom occurred without reflux, and reflux was frequently, though not invariably, associated with kidney scarring.

The incidence of reflux and kidney scarring was related to the duration of symptoms and the age at onset of symptoms.

Possible explanations of these findings are discussed.

Baker, R., Maxted, W., Maylath, J., and Shuman, I. (1966). Relation of age, sex and infection to reflux: data indicating high spontaneous cure rate in pediatric patients. $\mathcal{f}$.Urol. (Baltimore), 95, 27.

Fisher, H. E., Jr. (1965). Vesicoureteral reflux in childhood. A report of 25 cases. ibid., 94, 228.

Hodson, C. J., and Edwards, D. (1960). Chronic pyelonephritis and vesico-ureteric reflux. Clin. Radiol., 11, 219.

- -, and Wilson, S. (1965). Natural history of chronic pyelonephritic scarring. Brit. med. $\mathcal{F} ., 2,191$.

McGovern, J. H., Marshall, V. F., and Paquin, A. J., Jr. (1960) Vesicoureteral regurgitation in children. $\mathcal{F}$. Urol. (Baltimore), 83, 122.

Scott, J. E. S., and Stansfeld, J. M. (1968). Treatment of vesicoureteric reflux in children. Arch. Dis. Childh., 43, 323.

Smellie, J. M., Hodson, C. J., Edwards, D., and Normand, I. C. S. (1964). Clinical and radiological features of urinary infection in chiidhood. Brit. med. F., 2, 1222. 